\title{
Conservation and Literacy Values in Reading Lectures of Indonesian Language with Problem Based Learning Model
}

\author{
Asep Purwo Yudi Utomo' ${ }^{1}$ Isnarto $^{2}$, Arum Yuliya Lestari ${ }^{3}$ \\ \{aseppyu@mail.unnes.ac.id ${ }^{1}$, isnarto@mail.unnes.ac.id ${ }^{2}$, arumyl@gmail.com ${ }^{3}$ \} \\ ${ }^{1,3}$ Indonesian Language and Literature Department, Universitas Negeri Semarang,Indonesia \\ ${ }^{2}$ Mathematics Education Study Program, Universitas Negeri Semarang, Indonesia
}

\begin{abstract}
The main problems of learning are understanding the implementation of learning in schools, the lack of knowledge, or the weak of literacy, as well as the weakness of prospective teacher students ability in the development of learning. The realistic solution offered is the implementation of student-centered learning models, namely problem based learning. In addition, the strengthening of literacy awareness is also an important part in the steps of implementing a learning model that is strengthened by the conservation value as a characteristic of Semarang State University. This research used descriptive research, which prioritizes the description of exist events and take place at the time of learning. The research subjects were six reading learning classes in 2017 and 2018. The results of the study included three things, the effectiveness of reading lectures measured by the achievement of students average score who reached 83.75 for reading comprehension skills. The implementation of conservation value is seen in all steps of learning with a different of conservation value, from inspirational, humanist, caring, creative, and innovative values. Literacy implementation was described by lecturing assignments in the form of reading assistance by applying approaches, models, methods, and reading techniques.
\end{abstract}

Keywords: literacy, conservation value, learning to read, problem based learning

\section{INTRODUCTION}

Reading is as a receptive ability that has an important meaning in the development of knowledge and literacy. The good reading skills will help someone to gain knowledge and understanding related to the knowledge that is read or learned. According to Martinez (2018) [1] who described about the difficulty of reading skills students and influenced the understanding of another knowledge. Whereas Zimmerman (2006) [2] conveyed the relation between reading and literacy.

Besides being studied, reading has an important meaning in education. This is related to literacy which is currently used as one of the main programs of the government to overcome the lack of reading interest. A research conducted by Karademir (2017) [3] also discussed about the causal relationship among critical reading skills, critical skills, and an attitude of titration. The 
findings of this study confirm a significant and positive relationship between critical reading skills, literacy skills, and attitudes towards literacy.

For prospective Indonesian language teacher students, they learn to read not just how to read, however, the teacher must be able to teach. The good teaching skill is expected to be able to give students a good understanding as well. This is in line with a research conducted by Rennie (2011) [4] who stated the definition of professional learning conducted by secondary school teachers and literacy training. The research explained that one way to improve students' reading skills is to train their teachers with good reading skills. However, providing an understanding and skills to prospective teacher students is not an easy job. It occurs because of many aspects and problems.

One of the main problems in learning lectures is understanding the problems in implementing learning in schools, lack of knowledge about the basics of knowledge about the science or weak student literacy, and the ability of prospective teacher students in developing learning. For example if we as a homeschooling teacher must understand what is contained therein, as reviewed in the research of Guterman et al. (2019) [5] .

Therefore, it is necessary to implement an appropriate learning model, namely problem based learning. Problem based learning is used as a means of increasing criticism so that students are able to analyze what they have to do when they face new problems. In a study conducted by Mohson (2009) [6] who stated that problem based learning brings students to gain knowledge by practicing and analyzing.

Research related to this article was conducted by Koning (2016) [7], Accardo (2017) [8], Ely (2018) [9], Rosyida (2018) [10], Walgermo (2018) [11], Leko (2019) [12], who discussed reading learning implemented in various levels of education and related to literacy. Muhson (2009) [6], Fakhriyah (2014) [13], Nafiah (2014) [14], Ali (2019) [15], Markušić (2019) [16], conducted research that discussed the implementation of problem based learning model in various scientific studies. In addition, Glenberg (2011) [17], Walgermo (2018) [11] who studied reading and literacy skills.

Based on some of these studies can describe the position of the research conducted. In addition to measure the effectiveness of reading lectures, we also do two other things, namely implementing conservation value which is a value carried by the university and implementing literacy by involving all components.

\section{METHOD}

The research method used is descriptive qualitative and quantitative. Quantitative descriptive was conducted on the measurement of the effectiveness of reading lectures and qualitative learning was conducted to describe the implementation of conservation value and literacy in reading lectures.

The data was taken from six reading lectures classes in 2017 and 2018 to measure reading skills. Six classes taken for the data were semester 4 students who took reading lectures. The research subjects consisted of 195 students that divided into the following classes.

Table 1 Student Research Subjects

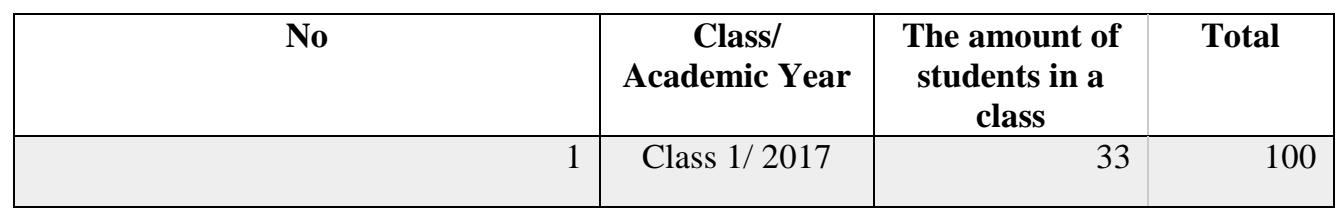




\begin{tabular}{|c|r|r|}
\hline \multirow{2}{*}{} & Class 2/ 2017 & 32 \\
\cline { 2 - 3 } & Class 3/ 2017 & 35 \\
\hline \multirow{2}{*}{2} & Class 1/2018 & 30 \\
\cline { 2 - 3 } & Class 2/ 2018 & 35 \\
\cline { 2 - 4 } & Class 3/ 2018 & 34 \\
\hline Total & 195 & 34 \\
\hline
\end{tabular}

The instruments used in this research are assessment instruments, observation sheets, and documentation. The assessment instrument was used to assess the results of reading lectures conducted in each class. The assessment carried out was to measure reading comprehension skills and effective reading speed. Observation sheets were used to help observers in observing the lectures. The main thing observed was student behavior and the implementation of conservation value in the lectures. This observation sheet was intended for the learning process only. In the preparation stage, a document review was used. The documentation in this research is to conduct an analysis of documents in the form of learning designs. In addition, learning process documents namely photo and pictures are also needed.

\section{RESULT AND DISCUSSION}

There are three discussions in this article, namely: the effectiveness of lectures on learning to read, the implementation of conservation value in learning to read, and the form of implementing literacy in learning to read.

\section{The Effectiveness of Reading Lectures}

The effectiveness of reading lectures was conducted through the test of reading comprehension or intensive reading skills as well as effective reading skills. The two assessments were carried out in two stages. Before conducting the test, students have studied and practiced in advance so there was a preliminary understanding related to the assessment conducted. The same research was conducted by Accardo (2017) [11] who measured reading comprehension skills.

From 6 classes tested in 2017 and 2018, the following reading comprehension scores were obtained.

Table 2 The Score of Reading Comprehension

\begin{tabular}{|r|r|r|r|r|}
\hline No & $\begin{array}{c}\text { Class/ } \\
\text { Academic Year }\end{array}$ & $\begin{array}{c}\text { The amount } \\
\text { of students in } \\
\text { a class }\end{array}$ & Average & Total \\
\hline 1 & Class 1/ 2017 & 33 & 87,54 & 2.889 \\
\hline 2 & Class 2/ 2017 & 32 & 84,50 & 2.704 \\
\hline
\end{tabular}




\begin{tabular}{|r|r|r|r|r|}
\hline 3 & Class 3/ 2017 & 35 & 81,23 & 2.843 \\
\hline 4 & Class 1/ 2018 & 30 & 85,17 & 2.555 \\
\hline 5 & Class 2/ 2018 & 31 & 84,55 & 2.621 \\
\hline 6 & Class 3/ 2018 & 34 & 79,97 & 2.719 \\
\hline & $\mathbf{1 9 5}$ & $\mathbf{8 3 , 7 5}$ & $\mathbf{1 6 . 3 3 1}$ & \\
\hline
\end{tabular}

From the 6 classes tested in 2017 and 2018, the following reading comprehension scores were obtained.

Table 3 The Score of Reading Comprehension

\begin{tabular}{|c|c|c|c|c|}
\hline No & $\begin{array}{c}\text { Class/ } \\
\text { Academic Year }\end{array}$ & $\begin{array}{l}\text { The Amount } \\
\text { of Student in } \\
\text { a Class }\end{array}$ & Average & Total \\
\hline 1 & Class 1/ 2017 & 33 & 395 & 13.035 \\
\hline 2 & Class 2/ 2017 & 32 & 388 & 12.416 \\
\hline 3 & Class 3/ 2017 & 35 & 332 & 11.620 \\
\hline 4 & Class 1/ 2018 & 30 & 380 & 11.400 \\
\hline 5 & Class 2/ 2018 & 31 & 350 & 10.850 \\
\hline \multirow[t]{2}{*}{6} & Class 3/ 2018 & 34 & 291 & 9.904 \\
\hline & 195 & $\begin{array}{l}355 \text { words } \\
\text { per minute }\end{array}$ & 69.225 & \\
\hline
\end{tabular}

These two results were satisfying results. Nevertheless, this satisfying result had been conducted through a long process. Haryadi et al. (2018) [18], had conducted a research that detected students' reading skills. It was concluded that students' reading abilities were still weak. Therefore, the right treatment was needed. In this research, there are two things to be conducted. First, the lecturer implemented an appropriate learning model, which was a problem based learning model that made students think critically and creatively. Second, conducted programmed training and mentoring so that students' skills were trained.

This is also in line with a research by Ozgur (2019) [19] who related reading skills with other language skills, especially writing. It means that the treatment that we conducted in problem based learning also helped students to obtain decription and knowledge so that students have the provision in reading comprehension and reading speed. So, in addition to the learning strategy also required a reading comprehension strategy, it was stated by Grisham (2008) [20] who implemented a reading comprehension strategy to improve learning outcomes in reading comprehension. 


\section{The Implementation of Conservation Value in Reading Lectures}

The implementation of conservation value was observation in all steps of learning. The intended learning step is the preparation, learning, and evaluation stage.

In the preparation stage, the learning plan was arranged. In the compiled learning design, the values concluded are inspirational, humanist, caring, creative, and innovative values that are spread throughout all stages of learning. The draft arranged is expected to be implemented well in the learning process.

At the learning stage, observations were conducted by observers who observed learning from beginning till end. In the varied learning, there was a dominant conservation value that appeared, namely inspirational and humanist. This value often appears in the core learning stages that apply the problem based learning model.

In the evaluation stage, students were tested with two tests, namely reading comprehension and effective speed of reading. In the evaluation, the dominant values are creative and innovative values.

\section{The Form of Literacy Implementation in Reading Lecturing}

The form of literacy implementation that we conducted involved lecturers, 4th semester students as a companion, and 2nd semester students as the subject of implementation. It was conducted so that there was a transfer of knowledge. The transfer of knowledge was done by applying four things. Applying assistance to approaches, models, methods, and reading techniques.

A similar thing was done by Nurie (2017) [21] who conducted a study on how teachers teach reading. Providing opportunities to practice is one of the best ways to develop reading skills.

The steps were taken in mentoring was divided into 3 main steps, the preparation stage, the mentoring stage, and the evaluation stage. In the preparation stage, 4th semester students made a mentoring design by analyzing the group's needs. It will include analyzing the approach, model, method, or technique that will be taught or delivered. At the implementation stage is implementing the design results. The implementation was carried out in various places according to the needs of the group. Mentoring activities could be done in classrooms, parks, gazebos, or other comfortable places. It was done so that activities were not boring. The evaluation stage carried out was to conduct an assessment as well as reflection. After obtaining the results, a discussion was carried out regarding the application of the approach, model, method, or technique practiced.

Through this assistance, there is a transfer of knowledge from senior students to junior students. By limiting the learning time, it is very helpful in increasing competition to both parties.

\section{CONCLUSION}

The conclusions of this article cover three things. First, reading lectures that implement the problem based learning model work effectively. The effectiveness of the study of reading lectures was measured from the achievement of the average score of students who reach 83.75. Second, reading lectures was carried out implementing conservation value as a value carried by the university. Implementation of conservation value is seen in all steps of learning with a different distribution of conservation value, namely inspirational, humanist, caring, creative, and innovative values. Third, the form of literacy implementation in reading lectures was carried 
out through continuous student assistance. Literacy implementation was described by lecturing assignments in the form of reading assistance by applying approaches, models, methods, and reading

techniques.

\section{REFERENCE}

[1] S. Vaughn, A.-M. Fall, G. Roberts, J. Wanzek, E. Swanson, and L. Martinez, "Class Percentage of Students With Reading Difficulties on Content Knowledge and Comprehension,” J. Learn. Disabil., vol. 52, p. 22219418775117 , May 2018.

[2] L. Zimmerman, "Lessons learnt: Observation of Grade 4 reading comprehension teaching in South African schools across the Progress in International Reading Literacy Study (PIRLS) 2006 achievement spectrum," Read. Writ., vol. 5, no. 1, pp. 1-9, 2014.

[3] E. Karademir and U. Ulucinar, "Examining the Relationship between Middle School Students' Critical Reading Skills, Science Literacy Skills and Attitudes: A Structural Equation Modeling,” J. Educ. Sci. Environ. Heal., vol. 3, no. 1, pp. 29-29, 2016.

[4] J. Rennie, "Learning to read: A professional learning journey," Aust. Educ. Res., vol. 38, pp. 221-238, May 2011.

[5] O. Guterman and A. Neuman, "Reading at Home: Comparison of Reading Ability Among Homeschooled and Traditionally Schooled Children," Read. Psychol., vol. 40, no. 2, pp. 169-190, Feb. 2019.

[6] A. Muhson, "Peningkatan Minat Belajar Dan Pemahaman Mahasiswa Melalui Penerapan Problem-Based Learning," J. Inst. Kegur. Ilmu Pendidik. Yogyakarta, vol. 39, no. 2, pp. 171-182, 2009.

[7] B. B. de Koning, L. T. Bos, S. I. Wassenburg, and M. van der Schoot, "Effects of a Reading Strategy Training Aimed at Improving Mental Simulation in Primary School Children," Educ. Psychol. Rev., vol. 29, no. 4, pp. 869-889, 2017.

[8] A. Accardo, E. Finnegan, S. Gulkus, and C. Papay, "TEACHING READING COMPREHENSION TO LEARNERS WITH AUTISM SPECTRUM DISORDER: PREDICTORS OF TEACHER SELF-EFFICACY AND OUTCOME EXPECTANCY: Reading Comprehension and ASD," Psychol. Sch., vol. 54, pp. 309-323, Mar. 2017.

[9] E. Ely, K. D. Alves, N. R. Dolenc, S. Sebolt, and E. A. Walton, "Classroom Simulation to Prepare Teachers to Use Evidence-Based Comprehension Practices," J. Digit. Learn. Teach. Educ., vol. 34, no. 2, pp. 71-87, 2018.

[10] F. Rosyida and M. Ali Ghufron, "Herringbone and tri focus steve snyder technique: The techniques for teaching reading comprehension viewed from students' reading habit," Int. J. Instr., vol. 11, no. 3, pp. 603-616, 2018.

[11] B. R. Walgermo, N. Foldnes, P. H. Uppstad, and O. J. Solheim, "Developmental dynamics of early reading skill, literacy interest and readers' self-concept within the first year of formal schooling," Read. Writ., vol. 31, no. 6, pp. 1379-1399, 2018.

[12] M. Leko, T. Alzahrani, and T. Handy, "Literacy Instruction for Adolescents with Learning Disabilities: Examining Teacher Practice and Preparation.," Learn. Disabil. A Contemp. J., vol. 17, no. 1, pp. 117-138, 2019.

[13] F. Fakhriyah, "Penerapan problem based learning dalam upaya mengembangkan kemampuan berpikir kritis mahasiswa," J. Pendidik. IPA Indones., vol. 3, no. 1, pp. 95$101,2014$.

[14] Y. N. Nafiah and W. Suyanto, "Penerapan model problem-based learning untuk meningkatkan keterampilan berpikir kritis dan hasil belajar siswa," J. Pendidik. Vokasi, vol. 4, no. 1, pp. 125-143, 2014. 
[15] S. Ali, "Problem Based Learning: A Student-Centered Approach," English Lang. Teach., vol. 12, p. 73, Apr. 2019.

[16] J. Markušić and J. Sabljić, "Problem-Based Teaching of Literature," J. Educ. Train. Stud., vol. 7, no. 4, p. 20, 2019.

[17] A. M. Glenberg, "How reading comprehension is embodied and why that matters," Int. Electron. J. Elem. Educ., vol. 4, no. 1, pp. 5-18, 2011.

[18] H. Haryadi, R. Arifudin, A. Utomo, and U. Yulianti, Identification of Students' Interest of Literacy At College As A Form Of Cultural Conservation. 2018.

[19] O. Babayigit, "Examining the effect of creative writing activities on reading, writing and language lesson attitudes of elementary school fourth grade students," Eur. J. Educ. Res., vol. 8, no. 1, pp. 213-220, 2019.

[20] L. Dana and D. L. Grisham, "Improving Reading Comprehension in K-12 Education : Investigating the Impact of the Reading Specialist Credential on the Instructional Decisions of Veteran Teachers," Issues Teach. Educ., vol. 17, no. 1, pp. 31-46, 2008.

[21] Y. Nurie, "Pedagogical Practices in Teaching Reading Comprehension: A Case Study of Three EFL Teachers in a Secondary School in Ethiopia.," PASAA J. Lang. Teach. Learn. Thail., vol. 54, no. December, pp. 108-140, 2017. 